\title{
Multiple myeloma
}

INSERM

\section{Source}

INSERM. (1999). Orphanet: an online rare disease and orphan drug data base. Multiple myeloma. ORPHA:29073

Multiple myeloma (MM) is a malignant tumor of plasma cell characterized by overproduction of abnormal plasma cells in the bone marrow and skeletal destruction. The clinical features are bone pain, renal impairment, immunodeficiency, anemia and presence of abnormal immunog lobulins (Ig). 